\title{
ARE INSPECTIONS CONDUCTED BY SELECTED ADMINISTRATIVE BODIES COMPLIANT WITH THE CONSTITUION OF THE SLOVAK REPUBLIC AND THE EUROPEAN CONVENTION ON HUMAN RIGHTS?
}

\author{
Lucia Smolková \\ Comenius University in Bratislava, Faculty of Law
}

\begin{abstract}
This paper analyses the case law of the Slovak Constitutional Court and the Slovak Supreme Court dealing with inspections conducted by selected Slovak administrative bodies - especially by the administrative bodies in the area of foodstuffs administration - where inspected companies complain that their rights guaranteed by the Slovak Constitution and the European Convention on Human Rights, namely the protection of their business premises, have been violated. The paper thus also deals with and analyses the related case law of the European Court of Human Rights and its (non)-application by the Slovak judicial bodies in their decision-making practice.
\end{abstract}

Key words: inspection, Supreme Court of the SR, Constitutional Court of the SR, fundamental rights and freedoms, business premises, Constitution, European Convention on Human Rights

\section{INTRODUCTION}

Inspections conducted by administrative bodies in the area of foodstuffs administration (namely by the Regional Food and Veterinary Administration of the Slovak Republic and the State Food and Veterinary Administration of the Slovak Republic) have recently been quite frequently disputed by companies subjected to them.

Given the wide range of powers enjoyed by the aforementioned administrative bodies in conducting their inspections, the companies claim that these administrative bodies violate their rights which are conferred upon them by the Constitution of the Slovak Republic ("Constitution") and the European Convention on Human Rights (“Convention”). They have been trying to defend themselves by arguing that these inspections are not permissible in consideration of the case law of the European Court of Human Rights ("ECtHR”) and the European Court of Justice (“ECJ”).

Food inspections were frequently reviewed by the Supreme Court of the Slovak Republic ("Supreme Court") on the basis of actions for unlawful interference of administrative bodies lodged by the relevant companies under the provisions of Act No. 99/1963 ("Code of Civil Procedure") and currently under Act No. 162/2015 Coll. ("Code of Administrative Justice") ${ }^{1}$ and later by the Constitutional Court of the Slovak Republic ("Constitutional Court") on the basis of constitutional complaints lodged under Act No. 38/1993 Coll. on the Organizational Structure of the Constitutional

The Code of Administrative Justice came into effect in Slovakia on 1 July 2016 replacing its predecessor - the Code of Civil Procedure - which, despite the fact that its title contains the term "civil", also dealt with the judicial review of decisions and processes of administrative bodies. Under the Code of Civil Procedure, it was the Supreme Court of the Slovak Republic which had jurisdiction over actions for unlawful interference of administrative bodies. 
Court of the Slovak Republic, on the Proceedings Conducted before the Court and on the Status of Its Justices ("Act on the Constitutional Court").

We believe that one of the key issues which need to be analysed in determining whether inspections conducted by the above-mentioned administrative bodies are compliant with the Constitution and the Convention is, inter alia, the protection of business premises enjoyed by companies. Protection of business premises became a debatable and questionable issue dealt with by the Supreme Court and the Constitutional Court namely in connection with inspections conducted by the Antimonopoly Office of the Slovak Republic ("AMO") which have also sparked outrage among companies given the fact that in conducting its inspections, the AMO enjoys a wide range of powers some of which, one could claim, even correspond to the criminal law institutes.

\section{BUSINESS PREMISES FROM HUMAN RIGHTS PERSPECTIVE}

\subsection{Right to the protection of business premises}

In the beginning, we have to say that there currently should be no doubt as to whether business premises enjoy any protection from human rights perspective, at least not in the decision-making practice of the ECtHR and the ECJ.

As for the Slovak law, there are a number of provisions contained in the Constitution which, we believe, could be applicable to the protection of business premises. Article 16(1) of the Constitution provides that "the inviolability of an individual and his privacy shall be guaranteed. Restriction of such inviolability is permissible only where the law so prescribes." Article 19(2) of the Constitution states that "everyone shall have the right to be protected from unlawful interference with his private and family life" and Article 21(1) of the Constitution provides that "home shall be inviolable and entrance without a consent given by the person residing therein is not permitted." Furthermore, Article 21(3) of the Constitution states that "other infringements of the inviolability of the home shall be legally justified only if it is necessary in a democratic society to protect life, health, or property, to protect rights and freedoms of others, or to avert a serious threat to public order. If the home is used for business or other economic activities, such infringements may be allowed by the law also for the purposes of fulfilling the tasks of public administration."

From our point of view, it is mainly Article 21 of the Constitution which, we believe, should be applicable to the protection of business premises (namely in consideration of the wording of its Section 3 where "business and other economic activities" are mentioned). However, Drgonec states that the foregoing provision applies only to those homes which are used for residential purposes and at the same time for carrying out business activities. ${ }^{2}$ In case of natural persons, this provision would most likely not cause any difficulties in its application. However, the situation differs in the application of this provision to artificial persons (companies in our case) which are not human beings capable of residing in a particular place. They, on the other hand, are very often created with the view to carry out a particular business activity. Given the fact that the protection guaranteed by Article 21 should apply to both natural as well as artificial persons, we therefore are still of the view that business premises of artificial persons should be protected in the same way as the homes of natural persons.

2 DRGONEC, J. Ústava Slovenskej republiky. Teória a prax. Bratislava : C. H. Beck, 2015, p. 559. 
However, the decision-making of the Constitutional Court does not support our aforementioned conclusion with respect to Article 21 of the Constitution. Despite this fact, we still personally believe that the approach and stand of the Constitutional Court in this regard has not fully developed yet given the fact that the Constitutional Court itself stated in one of its decisions that the law of inspections conducted in business premises (and thus the protection guaranteed to business and corporate premises) is currently developing both within the area of administrative law as well as the constitutional law. It further stated that the relevant case law established in this regard is thus still in progress and mainly established only with respect to the competition law. ${ }^{3}$

In one of its findings, the Constitutional Court argued quite surprisingly that business premises (in particular, the business premises of a retailer selling foodstuffs) cannot be subsumed under the term "home" used in Article 21 of the Constitution. It claimed that this term differs from the term "home" used in Article 8 of the Convention which shall be interpreted in a wider sense and shall thus also cover an office where an individual performs his/her liberal profession or, under special circumstances, it can also refer to a registered seat and business premises. ${ }^{4}$ The Constitutional Court explicitly stated that business premises of the above-mentioned company do not enjoy the protection under Article 21 of the Constitution but should be protected by other articles of the Constitution which provide for the protection of privacy. Although the Constitutional Court (unfortunately) failed to specify these particular articles of the Constitution, we believe that it most likely referred to Article 16(1) of the Constitution and Article 19(2) of the Constitution. ${ }^{5}$

In light of the above conclusions, according to the Constitutional Court, it is the term "privacy" which should be interpreted in a wider sense and should also include operational or business premises of companies. However, from our point of view, this conclusion of the Constitutional Court is rather confusing given the fact that Article 21(3) of the Constitution could, in our opinion, be interpreted in a way that the term "home" used in this article also covers premises where business or other economic activities are conducted and should thus also enjoy protection under Article 21. Even Drgonec actually notes in this regard that the term "home" should be construed more broadly due to the fact that the Constitutional Court should interpret the term "home" in accordance with the case law of the ECtHR. In addition to this, Drgonec also argues that the ECtHR stated that the term "home" used in the English language version of Article 8 of the Convention also covers business premises in some member states of the Council of Europe, e.g. in Germany. This interpretation is also in accordance with the French language version of the text where the term "domicile" could be interpreted in a wider extent than the term "home". A narrow interpretation of the term "home" and "domicile" could potentially lead to the risk of unfair treatment. ${ }^{6}$

The Convention states in its Article 8 that everyone has the right to respect for his private and family life, his home and his correspondence. Section 2 of this Article states that there shall be no interference by a public authority with the exercise of this right except such as is in accordance with the law and is necessary in a democratic society in the interests of national security, public safety or

3 See e.g. Resolution of the Constitutional Court No. II ÚS 446/2017-20.

4 See e.g. Finding of the Constitutional Court No. II ÚS 792/2016-62.

5 Given the fact that the Constitutional Court was not able to identify any causal link between the challenged violation of the right to the protection of home provided for in Article 21 and the facts described by the complainant in this case, it dismissed the constitutional complaint. We believe that such dismissal was based mainly on grounds of "formalities" thus enabling the Constitutional Court not to deal with the real subject matter (which the Constitutional Court actually did to a very limited extent).

6 DRGONEC, J. Ústava Slovenskej republiky. Teória a prax. Bratislava : C. H. Beck, 2015, p. 553 - 554. 
the economic well-being of the country, for the prevention of disorder or crime, for the protection of health or morals, or for the protection of the rights and freedoms of others. ${ }^{7}$ Schwarcz notes in this regard that the application of these provisions to artificial persons (companies) was not common at all in the past. ${ }^{8}$ Gradually, both the ECtHR and the ECJ inclined to a solution by which the rules contained in the above-mentioned provisions should be interpreted broadly, i.e. also in favour of artificial persons. In 2002, both the ECJ as well as the ECtHR definitely accepted the fact that Article 8 of the Convention shall be applied to business premises as well. One of the most important and ground-breaking judgement of the ECtHR was issued in its case Colas Est and Others v. France. ${ }^{9}$ The ECtHR ruled that the rights guaranteed by Article 8 of the Convention can be interpreted in a way that they, under some circumstances, also cover the right of a company to have its business seat, organizational units as well as professional or business premises respected. ${ }^{10}$

Even the ECJ expressed in one of its judgements ${ }^{11}$ that the exercise of powers of the Commission during its inspections under Article 20(4) of the Regulation No $1 / 2003^{12}$ is a clear interference with the right of a company to the respect of its private life, home and correspondence, thus acknowledging that companies enjoy this right.

\subsection{Limitations of the right to the protection of business premises}

Both the Constitution (Article 21(3) of the Constitution) as well as the Convention (Article 8(2) of the Convention) provide for certain limitations of the right to the protection of business premises. Comparing the relevant provisions contained therein, we can see that both the Constitution as well as the Convention state the following with respect to the possibility of limiting one's right to the protection of business premises. In both cases interference by an administrative body with the exercise of this right is permissible provided that such interference is (i) in accordance with the law, (ii) necessary in a democratic society, (iii) pursuing a legitimate aim. With respect to the third precondition, the Constitution in particular states that this legitimate aim consists in the protection of life, health, personal property, rights and freedoms of others, in averting a serious threat to public order or in the exercise of the tasks of public administration by administrative bodies. The Convention, on the other hand, provides that this legitimate objective covers national security, public safety or the economic well-being of the country, prevention of disorder or crime, protection of health or morals, or protection of the rights and freedoms of others.

The ECtHR has already developed quite a significant case law in this regard and has been applying a so called "three-stage test" (as we have already pointed out above in connection with the

7 The application of the Convention takes precedence over the application of the laws of the Slovak Republic only if the conditions set out in Article 154c(1) of the Constitution are met.

8 SCHWARCZ, J., STEC, A. Inšpekcia vo svetle európskeho práva. Available at <http://www.antimon.gov.sk/data/files/ 437_1-juraj-schwarcz.pdf>. [q. 2017-09-29].

9 Colas Est. and Others v. France, no. 37971/97 of 16 July 2002.

10 Point 41 of the given decision reads as follows: "[--]. Building on its dynamic interpretation of the Convention, the Court considers that the time has come to hold that in certain circumstances the rights guaranteed by Article 8 of the Convention may be construed as including the right to respect for a company's registered office, branches or other business premises."

11 Judgement of the Court of 18 June 2015, Deutsche Bahn and Others v Commission, C-583/13 P, EU:C:2015:404

12 Council Regulation (EC) No 1/2003 of 16 December 2002 on the implementation of the rules on competition laid down in Articles 81 and 82 of the Treaty. 
permissibility of interference) in determining whether inspections conducted by administrative bodies are in accordance with the Convention. In terms of the second precondition for a lawful interference, i.e. "necessity of interference", the ECtHR allows the states a certain level of discretion in determining such necessity, namely in cases where the rights of artificial persons are concerned. ${ }^{13}$ However, the ECtHR always examines whether the state sufficiently explains what such necessity consists in - whether this interference is proportional. In one of its first important judgements - the judgement rendered in the Colas case - the ECtHR stressed in its decision that the fact that employees of the respective French administrative bodies entered the registered seats of companies, their business premises and branches during their raids without prior judicial authorisations amounted to the violation of their right to the respect of their "home" under Article 8 of the Convention. Despite the fact that the ECtHR acknowledged that the raid was conducted in accordance with the law and did not lack the legitimate aim, it stated that the raid was not necessary in the democratic society. It eventually concluded that in analysing the proportionality of the raid, no sufficient guarantees against the abuse of the power to conduct the raid were provided. It further noted that the respective administrative body had exceptionally vast powers in this case and had no mandate granted by the judge. In addition to this, the ECtHR criticised the fact that no police officer was present during the raid. We could therefore derive some important rules from this judgement of the ECtHR, namely that the wide powers exercised by administrative bodies during their inspections can be balanced by both (i) the presence of an independent third person supervising such inspections and (ii) a mandate or an authorisation for such inspections granted by the judge. This is how the proportionality could, in the opinion of the ECtHR, be reached and how the second precondition for lawful interference be met. The approach of the ECJ in this regard is the same given the fact that even the ECJ stressed the importance of proportionality of interference in its judgement concerning the case Dow Chemical Iberica ${ }^{14}$ and noted that in conducting its inspections, the European Commission shall act not only in accordance with the law, but also in a way which is proportional to the aim pursued.

However, we can see a certain development in the decision-making practice of both the ECtHR and the ECJ in assessing the proportionality of interference. In this connection, both courts have stressed the importance of certain procedural guarantees which have to be observed under Article 8 of the Convention. Both courts namely dealt with an "expost" review of inspections of the business premises and concluded that in the case of a missing prior judicial authorisation for inspection, the proportionality of interference is still achieved by means of a later or subsequent judicial review of inspections. We can therefore see a certain shift from the notion of proportionality established in the earlier Colas case where the absence of a mandate granted by the judge (along with the absence of an independent third person supervising the inspection) automatically led to unlawful interference. The ECJ dealt with the above-mentioned issue in its judgement in case Deutsche Bahn and Others v Commission. ${ }^{15}$ Moreover, it also dealt with the fact whether the system established by Regulation No 1/2003 provides sufficient guarantees of protection in case of a missing prior judicial authorisation. ${ }^{16}$ The ECJ held and established a very important principle under which a missing prior

13 See e.g. the judgement of the ECtHR in Delta Pekárny, a. s. v. Czech Republic, no. 97/11.

14 Judgement of the Court of 17 October 1989, Dow Chemical Ibérica, SA, and others $v$ Commission, joined cases 97/87, 98/87 and 99/87, EU:C:1989:380.

15 Judgement of the Court of 18 June 2015, Deutsche Bahn and Others v Commission, C-583/13 P, EU:C:2015:404.

16 Even the ECtHR emphasized the importance of a due review of guarantees, particularly where inspections may be conducted without a prior judicial authorisation. See e.g. Harju v. Finland, no. 56716/09, Heino v. Finalnd, no. 56715/09. 
judicial authorisation may be compensated by a comprehensive and effective review made after the inspection, i.e. by an effective judicial review a posteriori. Furthermore, the ECJ stated in this particular case that there are altogether five categories of guarantees which may be provided in inspections conducted by the Commission: (i) justification of the decision to conduct an inspection, (ii) limitations imposed on the Commission during inspections, (iii) Commission may not resort to any violence during inspections, (iv) interference made with the assistance of state's bodies and (v) existence of a posteriori remedies.

The principle of subsequent effective judicial review was repeatedly emphasized in another landmark case dealt with by the ECtHR, in the case of Delta Pekárny, a. s. against the Czech Republic. Here, the ECtHR dealt with "effectiveness" of subsequent judicial review and held that the Czech law did not provide the complainant with any procedural tool to challenge the course of the inspection, i.e. purpose of the inspection, its aim, extent, necessity and proportionality. Neither the Czech Supreme Administrative Court reviewed these aspects of the inspection. It further criticised the fact that the competent courts did not deal with the analysis of the matters of fact based on which the Czech administrative body conducted the inspection.

\subsection{How do Slovak courts assess inspections conducted by administrative bodies in the area of foodstuffs administration?}

Food inspections by administrative bodies in the area of foodstuffs administration are conducted in accordance with Act of the Slovak National Council No. 152/1995 Coll. on Foodstuffs ("Act on Foodstuffs") and Regulation (EC) No 882/2004 of the European Parliament and of the Council of 29 April 2004 on official controls performed to ensure the verification of compliance with feed and food law, animal health and animal welfare rules ("Regulation on Official Controls"). During these food inspections companies have to allow inspectors to enter their business premises, provide them with information, explanation, data, documents, and allow them to inspect them, copy them, or take photographs, if necessary, and if any non-compliance is discovered on their part, different types of sanctions can be imposed on them (in cases of fines, these can sometimes have a "destructive" effect on companies and their business activities).

Companies (namely food retailers) have in these cases also been defending themselves against unlawful interference by administrative bodies by referring to the above-mentioned case law of the ECtHR and the ECJ concerning the protection of business premises, namely the landmark Colas case, which they believe should also be applicable to food inspections. One of the most debatable issue which arose in connection with food inspections is the absence of a prior judicial authorisation for conducting food inspections.

In light of Article 8 of the Convention, they have been arguing that administrative bodies may interfere with the protection of business premises only on the condition that such interference is in accordance with the law, pursues a legitimate aim and is necessary in the democratic society. According to them, administrative bodies do not respect the requirement of "necessity of interference" which, in accordance with the Colas case, is not satisfied especially if (i) administrative bodies exercise wide range of powers during their inspections (e.g. they have an exclusive right to set the number, duration and extent of inspections), (ii) inspections are conducted without a prior judicial authorisation and (iii) there is no independent third person supervising the course of inspections. In light of the Delta Pekárny case, they believe that "if the national law empowers administrative 
bodies to carry out their inspections without a prior judicial authorisation, it is always extremely important to ensure that adequate and sufficient guarantees against the abuse of this empowerment are provided - a company subjected to an inspection should primarily be able to verify the purpose of inspection."

Even companies subjected to inspections conducted by the Antimonopoly Office of the Slovak Republic ("AMO") $)^{17}$ have complained in a number of cases ${ }^{18}$ that the authorization for inspection issued by the AMO to its employees fails to specify its particular purpose or such purpose is specified rather broadly and thus does not enable companies to challenge the lack of connection between the documents required by inspectors and the real purpose of inspection. ${ }^{19}$ As we have already pointed out above, both the ECtHR and the ECJ have stressed the importance of justification of the decision to conduct an inspection being an important guarantee provided to companies during inspections (namely in the absence of a prior judicial authorisation for inspection). Such situation may otherwise lead to undesired fishing expeditions when the AMO requires that companies provide it with a large number of various documents and information which may be unrelated to the purpose of inspection and obtained in the hope of discovering any useful information for a later proceeding and punishment of the company.

However, these arguments have been rejected by the Constitutional Court. ${ }^{20}$ First of all, the Constitutional Court argues that the above-mentioned case law is not applicable to food inspections at all due to the fact that it concerns the competition law and not the food law. It notes that these two areas (their relevant legislation and inspections) should be distinguished between. The Constitutional Court noted that "inspections conducted in the area of competition law are aimed at examining documents, information and thoughts whereby the likelihood of infringement of company's privacy is higher. Food inspections are more visual and personal ones and their purpose is usually clearer beforehand." ${ }^{21}$

We personally believe (and thus share the opinion presented by the relevant companies) that the above-mentioned case law should also be applicable to food inspections due to the fact that (i) sanctions imposed for the discovery of any non-compliance with the relevant legislation are similarly serious, (ii) both the competition law and the food law fall within the field of public law, (iii)

17 The AMO conducts its inspections under the provisions of Section 22a of Act No. 136/2001 Coll. on Protection of Economic Competition.

18 See e.g. Resolution of the Constitutional Court No. II ÚS 319/2017-22.

19 The Supreme Court has already dealt with and criticized the issue of a broadly specified purpose of inspections in authorizations in a number of cases (see e.g. decisions of the Supreme Court No: 5 Sžnz 1/2015, 5 Sžnz 2/2015, 8 Sžnz 2/2015, 3 Sžz 1/2011) and stated that generally, such authorization for inspection constitutes a fundamental legal act based on which the AMO conducts inspections. Its lawfulness is a precondition for the lawfulness of further procedure undertaken by the AMO on the basis of an authorization. The Supreme Court emphasized the fact that the authorization should primarily be based on a reasonable suspicion that economic competition has been breached. The authorization shall be sufficiently justified and sufficiently specific. To put it unequivocally, the Supreme Court stated that the justification of an authorization to conduct inspections should contain the following information: (i) description of basic characteristic features of an alleged offence, (ii) specification of the relevant market, (iii) nature of an alleged restriction of competition, (iv) explanations leading to general indications (with a general specification of their nature and type) as well as material indications with respect to the entity suspected of being an accomplice. Furthermore, it is necessary to explain how the respective offence was committed and provide the most direct and exact specification of what an inspection is intended for and what it concerns.

20 See e.g. the Finding of the Constitutional Court No II. ÚS 792/2016-62, Resolution of the Constitutional Court No. II ÚS 446/2017-20.

21 Resolution of the Constitutional Court No. II ÚS 446/2017-20. 
both competition law and food law are aimed at the protection of consumers. Guarantees provided in Article 8 of the Convention (and even Article 16, Article 19 or 21 of the Constitution) should not be dependent on the type of an inspection or on administrative bodies conducting them, if in both cases such inspections concern the right to the protection of one's home. We believe that the purpose of these rights, in light of the decision-making practice of the ECtHR and the ECJ, primarily lies in the protection of companies from "fishing expeditions".

We strongly believe that these food inspections could truly turn into fishing expeditions in some cases given the fact that administrative bodies in the area of foodstuffs administration might be politically motivated to conduct them ${ }^{22}$ in order to be able to impose extremely high fines which the currently effective Act on Foodstuffs prescribes for repeated violations of the Act on Foodstuffs. ${ }^{23}$ The likelihood of discovering a repeated violation is extremely high in the area of foodstuffs and these devastating fines would thus be really imminent. Given the foregoing, we therefore firmly opine that it is crucially important to provide these companies with certain guarantees during inspections, such as those the lack of which has been criticised in the Colas case.

In assessing the lawfulness of food inspections, the Constitutional Court arrived at a very interesting conclusion in one of its decisions. ${ }^{24}$ The Constitutional Court assessed food inspections within the limits of Article 8(2) of the Convention and argued that (i) food inspections are conducted in accordance with the law, namely the Act on Foodstuffs, which does not even prescribe the requirement for a prior judicial authorisation (the precondition of legality is thus satisfied), (ii) food inspections are aimed at ensuring that food retailers comply with the relevant legislation (the precondition of legitimacy is thus satisfied), and (iii) food inspections are necessary in order to protect consumers, their life and health (the precondition of necessity is thus satisfied, too). Furthermore, the strongest argument used by the Constitutional Court is that even if a food inspection is conducted without a prior judicial authorisation (one of the requirements established in the Colas case) because this one is not statutorily prescribed, this inspection could still be compliant with the Convention provided that a subsequent effective judicial review follows. Slovak courts deal with such inspections on the basis of (i) actions for unlawful interference or (ii) actions for a judicial review of decisions rendered by the relevant administrative bodies. ${ }^{25}$

\section{CONCLUSION}

All things considered, what would be the right answer to the question used in the title of our paper? Generally, according to the Constitutional Court, the sensitive issue in these cases is always the right to the protection of business premises. Despite the fact that the Constitutional Court has stated that its decision-making practice and the notion of the constitutional right to the protection of business

22 This is solely our opinion based on some newspaper articles which we have read. See e.g. the following articles published online: <https://finweb.hnonline.sk/ekonomika/539774-jahnatek-hrozi-retazcom-likvidacnymi-pokutami>. [q. 2018-0529], <https://dennikn.sk/368803/tesco-uz-nie-jedine-milionovu-pokutu-vymeral-stat-uz-aj-kauflandu/>. [q. 2018-05-29].

23 E.g. Section 28(8) of the Act on Foodstuffs states that if there is any repeated violation of obligations for which a fine was imposed under Section 7 [of the Act on Foodstuffs] and such violation occurs within one year of the day on which the decision on imposing a fine becomes final, the inspection body may this time impose a fine in the amount of 1 to 5 million euro.

24 Finding of the Constitutional Court No. II ÚS 792/2016-62.

25 Ibidem. 
premises is still developing, we have to argue that this notion was established in the decision-making practice of the ECtHR and the ECJ long ago and is quite unequivocal. Business premises should enjoy the right to their protection under Article 8 of the Convention.

In terms of food inspections, the situation can be a bit more complicated given the fact that there are currently no decisions by the ECtHR or the ECJ made specifically in connection with food inspections. Therefore, the Constitutional Court seems to be quite "lost or uncertain" in assessing their compliance with the Constitution and the Convention. On the one hand, it states that food inspections are radically different from inspections in the area of competition law and thus the competition case law established by the ECtHR and the ECJ (which the parties concerned refer to) is not applicable to them. On the other hand, its strongest argument for confirming the compliance of food inspections with the Convention is derived from the competition case law established by the ECtHR and the ECJ. This approach thus seems to be quite confusing and might cause uncertainty.

As we have already mentioned and explained above, we believe that the competition case law should be applicable to food inspections. Therefore, in accordance with this belief and actually also the opinion presented by the Constitutional Court in its confusing finding referred to above, we would have to conclude that food inspections conducted without a prior judicial authorisation could be compliant with the Constitution and the Convention provided that these inspections are subsequently reviewed by the competent courts and such review is deemed as effective and comprehensive, i.e. concerning both the matters of fact and the points of law.

\section{Bibliography:}

Act No. 136/2001 Coll. on the Protection of Economic Competition

Act No. 162/2015 Coll. (Code of Administrative Justice)

Act No. 99/1963 Coll. (Code of Civil Procedure)

Act of the Slovak National Council No. 152/1995 Coll. on Foodstuffs

Regulation (EC) No 1/2003 of 16 December 2002 on the implementation of the rules on competition laid down in Articles 81 and 82 of the Treaty

Regulation (EC) No 882/2004 of the European Parliament and of the Council of 29 April 2004 on official controls performed to ensure the verification of compliance with feed and food law, animal health and animal welfare rules

Decision of the Supreme Court of the Slovak Republic No. 5 Sžnz 1/2015 of 25 June 2015

DRGONEC, J. Ústava Slovenskej republiky. Teória a prax. Bratislava : C. H. Beck, 2015. 1603 s. ISBN 978-80-89603$39-8$.

Finding of the Constitutional Court of the Slovak Republic No II. ÚS 792/2016-62

GYARFÁŠ, J. Najvyšší súd k inšpekciám PMÚ: “Tak takto teda nie”. Available at <http://www.lexforum.cz/558>. [q. 2018-05-29].

Judgement of the Court of 17 October 1989, Dow Chemical Ibérica, SA, and others v Commission, joined cases 97/87, 98/87 and 99/87, EU:C:1989:380

Judgement of the Court of 18 June 2015, Deutsche Bahn and Others v Commission, C-583/13 P, EU:C:2015:404

Judgement of the ECtHR in Colas Est. and Others v. France, no. 37971/97.

Judgement of the ECtHR in Delta Pekárny, a. s. v. Czech Republic, no. 97/11

Judgement of the ECtHR in Harju v. Finland, no. 56716/09

Judgement of the ECtHR in Heino v. Finalnd, no. 56715/09.

Resolution of the Constitutional Court No. II ÚS 319/2017-22 
ARE INSPECTIONS CONDUCTED BY SELECTED ADMINISTRATIVE BODIES COMPLIANT WITH THE CONSTITUION OF THE SLOVAK REPUBLIC...

Resolution of the Constitutional Court No. II ÚS 446/2017-20

SCHWARCZ, J., STEC, A. Inšpekcia vo svetle európskeho práva. Available at <http://www.antimon.gov.sk/data/ files/437_1-juraj-schwarcz.pdf >. [q. 2018-05-29].

\section{Contact information:}

Mgr. Lucia Smolková

lucia.smolkova@flaw.uniba.com

Faculty of Law, Comenius University

Šafárikovo nám. č. 6

81000 Bratislava

Slovakia 